\title{
The effects of sildenafil in liver and kidney injury in a rat model of severe scald burn: a biochemical and histopathological study
}

\author{
Ali Kağan Gökakın, M.D., ${ }^{1}$ Mustafa Atabey, M.D., ${ }^{1}$ Koksal Deveci, M.D., ${ }^{2}$ \\ Enver Sancakdar, M.D., ${ }^{2}$ Mehmet Tuzcu, M.D., ${ }^{3}$ Cevdet Duger, M.D., ${ }^{4}$ Omer Topcu, M.D. ${ }^{1}$
}

\begin{abstract}
${ }^{1}$ Department of General Surgery, Cumhuriyet University Faculty of Medicine, Sivas;
${ }^{2}$ Department of Biochemistry, Cumhuriyet University Faculty of Medicine, Sivas;

${ }^{3}$ Department of Pathology, Cumhuriyet University Faculty of Veterinary, Sivas;

${ }^{4}$ Department of Anesthesiology, Cumhuriyet University Faculty of Medicine, Sivas
\end{abstract}

\begin{abstract}
BACKGROUND: Severe burn induces systemic inflammation and reactive oxygen species leading to lipid peroxidation which may play role in remote organs injury. Sildenafil is a selective and potent inhibitor of cyclic guanosine monophosphate specific phosphodiesterase-5. Sildenafil reduces oxidative stress and inflammation in distant organs. The aim of the present study was to evaluate the effects of different dosages of sildenafil in remote organs injury.
\end{abstract}

METHODS: A total of thirty-two rats were randomly divided into four equal groups. The groups were designated as follows: Sham, Control, 10, and T20 mg/kg sildenafil treatment groups. Levels of malondialdehyde (MDA), vascular endothelial growth factor (VEGF), VEGF receptor (FIt-I), activities of glutathione peroxidase (Gpx), levels of total antioxidative capacity (TAC), and total oxidant status (TOS) were measured in both tissues and serum, and a semi-quantitative scoring system was used for the evaluation of histopathological findings.

RESULTS: Sildenafil increased levels of Gpx, and Flt-I, and decreased MDA and VEGF levels in tissues. Sildenafil also increased serum levels of TAC and Flt-I and decreased TOS, OSI, and VEGF.

CONCLUSION: Sildenafil decreased inflammation scores in remote organs in histopathological evaluation. It has protective effects in severe burn-related remote organ injuries by decreasing oxidative stress and inflammation.

Key words: Remote organ injury; scald burn; sildenafil.

\section{INTRODUCTION}

Burn is a posttraumatic inflammatory disease accompanied by both local and distant effects leading to intense inflammation, tissue damage, and infection. ${ }^{[I]}$ Although a considerable progress in the management of burns has been achieved, systemic inflammatory response syndrome (SIRS), sepsis, and multiple

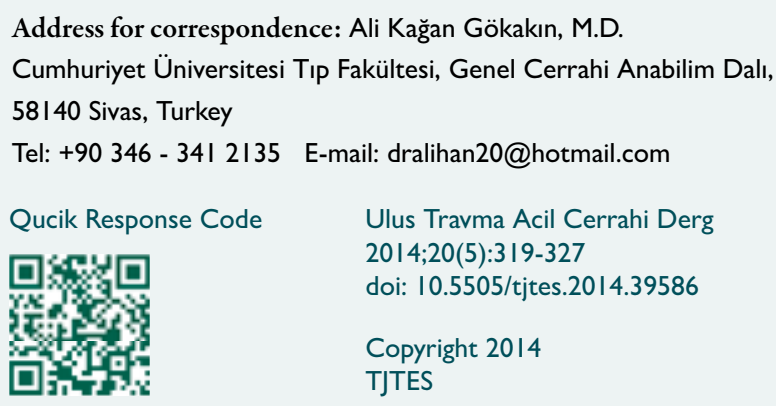

organ failure (MOF) still continue to be leading causes of mortality and morbidity in severe burn patients. ${ }^{[1-4]}$ The response to the initial burn is often associated with secondary damage to vital organs such as lung, liver, and kidneys, which are distant from the injured site. ${ }^{[4-9]}$ The pathophysiological mechanism of such remote organ injury in severe burn remains unclear. However, animal models and clinical trials of burn injury implicate that reactive oxygen species (ROS) and reactive nitrogen species (RNS) mediated by elevated proinflammatory mediators released from both the gut and the burn site can act as causative agents in the development of distant organ injury. ${ }^{[1,9-14]}$

The proinflammatory effects of ROS and RNS include endothelial damage, neutrophil reinforcement, cytokine release, and mitochondrial injury. Thus, remote organ injury following severe burn appears to be mediated by ROS and RNS via the formation of oxidative and nitrosative stress as a consequence of inflammatory response. ${ }^{[1,9,15,16]}$ Inflammation has 
been defined as a process induced by injury that normally leads to healing and is an essential component of physiological and /or pathological angiogenesis in most organs. Inflammatory cells surrounding the microvasculature can have a profound effect on promoting new vessel growth via vascular endothelial growth factor (VEGF) and VEGF receptors such as VEGF Receptor-I (FIt-I). ${ }^{[17-19]}$ However, the roles of VEGF and VEGF decoy receptor Flt-I in pathophysiological events, such as oxidative and nitrosative damage secondary to inflammation, are still in the area of active research. ${ }^{[17,19-24]}$

Effects of different agents on oxidative damage due to severe burn injury were evaluated in remote organs such as the lung, liver, gut and kidney in previous studies. ${ }^{[4,9,25-28]}$ Sildenafil is known as a selective and potent inhibitor of cyclic guanosine monophosphate (cGMP) specific phosphodiesterase-5 (PDE-5). PDE-5 catalyzes the hydrolysis of cGMP. Inhibition of PDE-5 causes increased concentration of cGMP and cyclic adenosine monophosphate (cAMP). The cyclic nucleotides cAMP and cGMP are second messengers playing major roles in various cellular processes, such as inflammation. ${ }^{[29]}$ Sildenafil induces endothelial nitric oxide synthase (eNOS) and inducible nitric oxide synthase (iNOS) generating nitric oxide (NO). Thus, sildenafil has a relaxant effect on smooth muscle cells of the arterioles and via NO dependent mechanism and may induce blocking of VEGF activity by a neutralized antibody against VEGF receptors as well as augment angiogenesis. ${ }^{[23]}$ However, most of these effects appear to be dosage dependent due to the levels of generated NO. ${ }^{[20]}$ Moreover, the beneficial effects of sildenafil have been shown in the balance of oxidation and antioxidation via decreasing oxidative and nitrosative stress in inflammatory events. ${ }^{[9,23,30-34]}$

However, there is no study in the literature focusing on the effects of sildenafil in remote organ injury induced by severe burn except our previous study focusing on acute lung injury. [9] The purpose of the present study was to evaluate the effects of different dosages of sildenafil in distant organs, such as liver and kidneys, due to severe scald burn injury in rats.

\section{MATERIALS AND METHODS}

The research was conducted in accordance with the Guide for the Care and Use of Laboratory Animals published by the US National Institutes of Health (NIH Publication no. 85-23, revised 1996) and approval has been received from the Institutional Animal Ethics Committee at Cumhuriyet University.

\section{Animals}

A total of thirty-two adult female Wistar Albino rats weighing between 200-250 g were included in the study. Animals were provided by the Experimental Animals Center, Cumhuriyet University, Sivas, Turkey. The animals were fed ad libitum with standard diet and water throughout the experiment. All animals were housed separately and kept under standard condi- tions of room temperature $\left(22-24^{\circ} \mathrm{C}\right)$ and a $12 \mathrm{~h}$ light/ $/ 2 \mathrm{~h}$ dark cycle.

\section{Burn Procedure}

Animals were anesthetized with (i.p.) xylazine $(5 \mathrm{mg} / \mathrm{kg})$ and ketamine $(30 \mathrm{mg} / \mathrm{kg})$ during the scalding and burn procedure, and $\mathrm{I} \mathrm{mg} / \mathrm{kg}$ morphine was administered intra-muscular just before immersing each of them to the boiling water. The dorsal surfaces of the rats were shaved closely, and the rats were secured in a constructed template device. The surface area of the skin on the dorsal surface exposed through the template device was immersed in $98{ }^{\circ} \mathrm{C}$ water for $12 \mathrm{~s}$. All test animals were quickly dried after each exposure to avoid additional injury. With the use of this technique, full-thickness dermal burns comprising $30 \%$ of the total body surface area (TBSA) were obtained. ${ }^{[25]}$

\section{Chemicals}

All the chemicals used in the experiments were purchased from Sigma Chemical Co. (Munich, Germany) except for Sildenafil which was obtained from Pfizer (Istanbul, Turkey).

\section{Experimental Design}

Animals were randomly divided into four equal groups as follows: Group S (no burn, no medication), Group C (scald control) was administrated per orally (p.o) $2 \mathrm{ml} 0.09 \% \mathrm{NaCl}$, Group TIO (Treatment with sildenafil $10 \mathrm{mg} / \mathrm{kg}$ ): $10 \mathrm{mg} / \mathrm{kg}$ p.o sildenafil, and Group T20 (Treatment with sildenafil $20 \mathrm{mg} / \mathrm{kg}$ ): $20 \mathrm{mg} / \mathrm{kg}$ p.o. sildenafil just after the scald burn. All animals were administered $4 \mathrm{ml} / \mathrm{l} 00 \mathrm{~g}$ body weight of lactated Ringer's solution subcutaneously just after the burn injury for fluid resuscitation according to parkland formula. Later, all animals were located in their own cages and let free to reach food and water. The reason for the selection of 10 and $20 \mathrm{mg} / \mathrm{kg}$ doses of oral sildenafil was that $10 \mathrm{mg} / \mathrm{kg} /$ day of sildenafil would result approximately in the same plasma concentration as $50 \mathrm{mg}$ in humans. ${ }^{[35]}$ These doses are very common for rats and our first aim was to determine whether it was protective in burn induced organ damage, as well as how the dose affected protection. All animals were sacrificed at the 24th hour after the scald burn via an overdose of a general anesthetic (thiopental sodium, $50 \mathrm{mg} / \mathrm{kg}$ ). Blood samples of the animals were collected in tubes for biochemical analysis, and liver and kidneys were harvested from all rats and washed in ice cold saline.

Half of the tissues were transferred to the biochemistry laboratory to be kept at $-80^{\circ} \mathrm{C}$ for biochemical analyses and the other half were fixed in $10 \%$ formalin solution for histopathological analysis.

Levels of malondialdehyde (MDA), VEGF, Flt-I, the activities of glutathione peroxidase (Gpx), levels of total antioxidative capacity (TAC), and total oxidant status (TOS) were measured in both tissue and serum. Oxidative stress index (OSI) was also calculated in tissue and serum. Additionally, ratios 
of VEGF/Flt-I in tissue and serum were calculated. A semiquantitative scoring system was used for the evaluation of histopathological findings which was used in our previous study ${ }^{[9]}$ (Table I).

\section{Biochemical Investigation of the Tissues}

In order to prepare the tissue homogenates, tissues were ground with liquid nitrogen in a mortar. The ground tissues $(0.5 \mathrm{~g}$ each) were then treated by $\mathrm{I} \mathrm{ml}$ of homogenization buffer per $100 \mathrm{mg}$ of tissue. The mixtures were homogenized on ice using an Ultra-Turrax Homogenizer for $15 \mathrm{~min}$. The homogenates were filtered and centrifuged, using a refrigerated centrifuge at $10,000 \times \mathrm{g}$ for $15 \mathrm{~min}$ at $4^{\circ} \mathrm{C}$. Supernatants and assay samples were collected according to the kit booklet protocol. All assays were performed at room temperature in duplicate.

\section{Biochemical Investigation of the Serum}

Blood was collected without using an anticoagulant, and then was allowed to clot for $30 \mathrm{~min}$ at $25^{\circ} \mathrm{C}$. Afterwards, blood samples were centrifuged at $2,000 \times \mathrm{g}$ for $15 \mathrm{~min}$ at $4^{\circ} \mathrm{C}$, and serum layers were pipetted off without disturbing the white buffy layers. Subsequently, serums were stored on ice and samples were frozen at $-80^{\circ} \mathrm{C}$.

\section{Measurement of MDA, Gpx, VEGF, and Flt-1}

All analyses were made for each parameter according to the protocols of each kit manufacturer's requirements.

As an index of lipid peroxidation and free radical generation, MDA content in the tissue supernatant and serum was measured by the MDA-586 method using a Bioxytech MDA-586 assay kit (Oxis Research, Oregon, USA). ${ }^{[36]}$ Protein concentration was determined by the Beckman Protein Assay on a Synchron ${ }^{\circledast} I$ × 20 analyzer (Beckman Coulter, 95942 Villepointe-Roissy-CDG, France) using BSA as a standard. MDA levels in the tissue supernatant were normalized against protein (pmol/g). Gpx was measured as a marker of enzymatic defense against ROS. Gpx activity in tissues and blood were measured spectrophotometrically using Cayman's standard glutathione (GSH) assay kit (Cayman Chemical Company, Ann Arbor, MI, USA). ${ }^{[3]]}$ Gpx activity in tissue supernatant was normalized against protein $(\mathrm{nmol} / \mathrm{min} / \mathrm{g})$. VEGF and Flt-I were measured in both serum and tissues in order to identify the effects of sildenafil in vascular permeability as well as angiogenesis and inflammation. Concentrations of VEGF and FIt-I were measured using two ELISA kits (RayBiotech. Inc., Norcross, GA, USA and Cusabio Biotech Co., Wuhan, Hubei Province, China). Values were calculated and converted to picograms per gram for tissues (pg/g), and picograms per milliliter for serum ( $\mathrm{pg} / \mathrm{ml}){ }^{[21,22]}$ Ratios of VEGF/FIt-I in tissues and serum were calculated in order to evaluate the local and systemic effects of sildenafil in the NO - VEGF/FIt-I relationship and assess the correlation between histopathologic findings and VEGF/FIt-I ratios.

\section{Measurement of TOS, TAC, and OSI}

TOS and TAC levels were measured using a spectrophotometric kit (Rel Assay Diagnostics, Gaziantep, Turkey,) ${ }^{[3,39]}$ Levels of TOS and TAC were assayed in an autoanalyzer (Beckman Coulter LX 20, Inc., Fullerton, CA, USA). Results of serum levels were expressed as millimolar Trolox (Rel Assay Diagnostics) equivalent per liter (L). TOS and TAC levels in the tissue supernatants were normalized against protein (mmol Trolox Equiv/g). The ratio of TOS to TAC was accepted as the OSI.

\section{Histopathological Evaluation of the Specimens}

Tissue samples were fixed in $10 \%$ buffered formalin for two days. Later each liver and kidney tissue samples were processed routinely and embedded in paraffin. After embedding, $5-\mu \mathrm{m}$ thick sections were taken from the tissue blocks and stained with hematoxylin and eosin (HE). Light microscope (X260) was used for histopathologic examination. The degree of the inflammation and destruction were scored for each group (Table I). A pathologist unaware of the group assignment analyzed samples. A mean score for each of the variables was then calculated. A total histopathological score (maximum 14) was derived from the sum of the mean scores of the four variables. All the samples were reviewed by the same pathologist to achieve correct score and mean value of each group was used for statistical analysis.

\section{Statistical Analysis}

Statistical analysis was performed with the Statistical Package for the Social Sciences for Windows (SPSS version 15.0, Chicago, IL, USA). All values were expressed as mean \pm standard deviation (SD). Comparison of variables between the groups was performed with Kruskal-Wallis test and Mann-Whitney

Table I. Scoring of inflammation and destruction in organs

\begin{tabular}{lll}
\hline Organ & Pathological Lesions & Score \\
\hline Liver & Hyperemia & 1 \\
& Cloudy swelling of hepatocytes & 1 \\
& Vacuolar degeneration & 2 \\
& Mononuclear cell infiltration & 2 \\
& Necrosis in hepatocytes (I-3 hepatocytes) & 2 \\
& Necrosis in hepatocytes (>3 hepatocytes) & 3 \\
Kidney & Hemorrhage & 3 \\
& Hyperemia & 1 \\
& Expansion of glomerular space & 1 \\
& Mesangial cell hyperplasia in glomeruli & 2 \\
& Degeneration of tubular epithelium & 2 \\
& Mononuclear cell infiltration & 2 \\
& Tubular epithelial necrosis & 3 \\
& Hemorrhage & 3 \\
\hline
\end{tabular}


$U$-test. Significance between histopathological scorings was determined with the chi-square test and Fisher's exact test. A correlation analysis (Speerman test) was used to assess the relationship between histopathological scorings and VEGF/ Flt-I ratios. A value of $\mathrm{p}<0.05$ was considered as statistically significant.

\section{RESULTS}

During the experimental period, only one death was observed in Group C and was seen in the first $12 \mathrm{~h}$. There was no statistically significant difference in mortality between groups.

\section{Levels of MDA, Gpx, VEGF, Flt-1, TAC, TOS} and OSI in Liver Tissues

Liver tissue levels of MDA, Gpx, VEGF, Flt-I, TAC, TOS and OSI were exhibited in Table 2. The lowest MDA levels were detected in Group S and Group TIO (I.I5 \pm 0.95 and $1.08 \pm 0.37 \mathrm{pmol} / \mathrm{g} /$ tissue, respectively). Significant differences were found between Group $S$ and Group $C(p=0.002)$, and between Group C and Group TI0 ( $=0,009)$.

The highest increase was detected in Group TI0 (9.52 1.48 $\mathrm{nmol} / \mathrm{min} / \mathrm{g} /$ tissue) in terms of Gpx levels and this increase rate was statistically different when compared to Group C $(p=0.04)$ and Group T20 ( $p=0.017)$; however, no difference was detected between Group TIO and Group S.

There was a significant increase in VEGF levels in Group TI0 when compared to Group S (0.003), Group C (0.018), and Group T20 (0.00I). Interestingly enough, VEGF levels were lower in Group T20 than in Group C, but this increase was not statistically significant $(p=0.179)$. A trend of increase was found in Flt-I levels in treatment groups, but there was only a significant difference between Group C and Group T20 ( $p=0.001$ ).

TAC levels were detected significantly higher in Group S than in Group C (0.00I), Group TI0 (0.002), and Group T20 (0.002). Also, TAC levels were statistically higher in Group TIO than in Group C ( $p=0.009)$. There was no difference between the four groups in terms of TOS levels. OSI levels were detected in significantly lower levels in Group TIO $(p=0.008)$ than in Group C.

Levels of MDA, Gpx, VEGF, Flt-1, TAC, TOS, and OSI in Kidney Tissues

Kidney tissue levels of MDA, Gpx, VEGF, Flt-I, TAC, TOS,

Table 2. Tissue levels of MDA, Gpx, VEGF, FIt-I, TAC, TOS and OSI in liver

\begin{tabular}{|c|c|c|c|c|c|c|c|}
\hline Groups & $\begin{array}{c}\text { MDA } \\
\text { (pmol/g/ } \\
\text { tissue) }\end{array}$ & $\begin{array}{c}\text { Gpx } \\
\text { (nmol/min/g/ } \\
\text { tissue) }\end{array}$ & $\begin{array}{l}\text { VEGF } \\
\text { (pg/g) }\end{array}$ & $\begin{array}{l}\text { Flt-I } \\
\text { (pg/g) }\end{array}$ & $\begin{array}{c}\text { TAC } \\
\text { (mmol Trolox } \\
\text { Equiv/g) }\end{array}$ & $\begin{array}{c}\text { TOS } \\
\text { (mmol Trolox } \\
\text { Equiv/g) }\end{array}$ & $\begin{array}{c}\text { OSI } \\
\text { (Arbitrary } \\
\text { Units) }\end{array}$ \\
\hline Group S & $1.08 \pm 0.37^{b}$ & $10.97 \pm 1.38^{\mathrm{b}, \mathrm{d}}$ & $6.94 \pm I .4 I^{c}$ & $24.03 \pm 1.32$ & $4.70 \pm 0.86^{b, c, d}$ & $10.06 \pm 1.47$ & $2.17 \pm 0.3 I^{b}$ \\
\hline Group C & $3.93 \pm 0.92^{\mathrm{a}, \mathrm{c}}$ & $3.06 \pm 0.73^{\mathrm{a}, \mathrm{c}}$ & $7.8 I \pm 0.83^{c}$ & $21.30 \pm 1.65^{d}$ & $2.14 \pm 0.28^{a, c}$ & $|5.3| \pm|.4|$ & $8.06 \pm 1.55^{\mathrm{a}, \mathrm{c}}$ \\
\hline Group SIO & $1.15 \pm 0.95^{b}$ & $9.52 \pm 1.48^{\mathrm{b}, \mathrm{d}}$ & $10.62 \pm 0.45^{\mathrm{a}, \mathrm{b}, \mathrm{d}}$ & $26.03 \pm 1.70$ & $3.51 \pm 0.13^{\mathrm{a}, \mathrm{b}}$ & $11.61 \pm 1.33$ & $3.30 \pm 0.4 I^{b}$ \\
\hline Group S20 & $2.53 \pm 0.12$ & $4.61 \pm 0.99^{a, c}$ & $6.40 \pm 0.10^{c}$ & $31.07 \pm 0.53^{b}$ & $2.90 \pm 0.25^{\mathrm{a}}$ & $13.42 \pm 1.68$ & $4.90 \pm 0.71$ \\
\hline
\end{tabular}

Results are means \pm SD of two measurements. MDA: Malondialdehyde; Gpx: Glutathione peroxidase; VEGF: Vascular endothelial growth factor; Flt-I: VEGF receptor; TAC: Total antioxidative capacity; TOS: Total oxidant status, OSI: Oxidative stress index.

a: Significantly different when compared to Group S; b: Significantly different when compared to Group C. c: Significantly different when compared to Group SI0; d: Significantly different when compared to Group S20. Comparison of variables between the groups was performed with Kruscal-Wallis test and Mann-Whitney $U$ test.

Table 3. Tissue levels of MDA, Gpx, VEGF, FIt-I, TAC, TOS, and OSI in kidney

\begin{tabular}{|c|c|c|c|c|c|c|c|}
\hline Groups & $\begin{array}{c}\text { MDA } \\
\text { (pmol/g/ } \\
\text { tissue) }\end{array}$ & $\begin{array}{c}\text { Gpx } \\
\text { (nmol/min/g/ } \\
\text { tissue) }\end{array}$ & $\begin{array}{l}\text { VEGF } \\
\text { (pg/g) }\end{array}$ & $\begin{array}{l}\text { Flt-I } \\
\text { (pg/g) }\end{array}$ & $\begin{array}{c}\text { TAC } \\
\text { (mmol Trolox } \\
\text { Equiv/g) }\end{array}$ & $\begin{array}{c}\text { TOS } \\
\text { (mmol Trolox } \\
\text { Equiv/g) }\end{array}$ & $\begin{array}{c}\text { OSI } \\
\text { (Arbitrary } \\
\text { Units) }\end{array}$ \\
\hline Group S & $1.09 \pm 0.16^{\mathrm{b}, \mathrm{d}}$ & $8.44 \pm 1.69^{b}$ & $8.96 \pm 1.63^{b}$ & $19.18 \pm 1.67^{c}$ & $4.01 \pm 0.15$ & $7.66 \pm 0.84$ & $1.91 \pm 0.74$ \\
\hline Group C & $3.12 \pm\left. 0.3\right|^{a, c, d}$ & $1.68 \pm 0.53^{a, c, d}$ & $13.06 \pm 0.69^{a, c, d}$ & $22.44 \pm 2.09^{c}$ & $2.50 \pm 0.20$ & $17.84 \pm 4.02^{\mathrm{d}}$ & $7.31 \pm 1.85$ \\
\hline Group SIO & $1.26 \pm 0.1 I^{\mathrm{b}, \mathrm{d}}$ & $6.73 \pm 1.33^{b}$ & $10.22 \pm 0.90^{\mathrm{b}}$ & $30.76 \pm 2.17^{\mathrm{a}, \mathrm{b}, \mathrm{d}}$ & $3.37 \pm 0.42$ & $9.67 \pm 1.52$ & $3.08 \pm 0.47$ \\
\hline Group S20 & $2.36 \pm 0.35 a, b, c$ & $5.87 \pm 0.7 \mathrm{lb}$ & $9.45 \pm 0.2 \mathrm{lb}$ & $23.60 \pm 0.88 c$ & $2.83 \pm 0.30$ & $8.41 \pm 1.07^{b}$ & $3.73 \pm 1.12$ \\
\hline
\end{tabular}

Results are means \pm SD of two measurements. MDA: Malondialdehyde; Gpx: Glutathione peroxidase; VEGF: Vascular endothelial growth factor; Flt-I: VEGF receptor; TAC: Total antioxidative capacity; TOS: Total oxidant status, OSI: Oxidative stress index.

a: Significantly different when compared to Group S; b: Significantly different when compared to Group C; c: Significantly different when compared to Group SIO.

d: Significantly different when compared to Group S20. Comparison of variables between the groups was performed with Kruscal-Wallis test and Mann-Whitney U test. 
and OSI were exhibited in Table 3. The lowest MDA levels were detected in Group S $(1.09 \pm 0.16)$ and in Group TI0 (l.26 $\pm 0.1 \mathrm{l} \mathrm{pmol} / \mathrm{g} /$ tissue). There was a statistically significant difference between Group C and T10 and T20 Groups $(p=0.00 \mathrm{I}$ and $p=0.034)$; whereas a similar significant difference was detected between TIO and T20 Groups $(p=0.001)$.

The highest increase was detected in group TI0 (6.733 \pm 1.33 $\mathrm{nmol} / \mathrm{min} / \mathrm{g} /$ tissue) in terms of Gpx levels and this increase rate in Group TI0 was statistically different when compared to Group C $(p=0.006)$; also, Gpx levels were significantly higher in Group T20 ( $p=0.018)$ than in Group C; however, no difference was detected between Group TI0 and Group T20.

There were significant decreases in VEGF levels in Group TIO $(p=0.026)$ and Group T20 $(p=0.003)$ compared to Group C; however, no statistical difference was found between Groups TIO and T20. Flt-I levels were significantly higher in Group TIO than in Group C ( $p=0.013)$, and Group T20 $(p=0.022)$, but no difference was found between Group C and Group T20.

There were no differences between the groups in terms of TAC, TOS and OSI levels except only in Group T20 whose TOS levels were detected lower than in Group $C(p=0.028)$.

\section{Levels of MDA, VEGF, Flt-1, Gpx, TAC, TOS,} and OSI in Serum

Levels of MDA, Gpx, VEGF, Flt-I, VEGF/FIt-I, TAC, TOS, and OSI in serum were shown in Table 4. MDA levels were the lowest in Groups S $(1,27 \pm 0,24)$ and TIO $(1,54 \pm 0,39)$ and it was significant when compared to Group $C(p=0,001)$. There were no differences between Groups T10 and T20.

Gpx levels were significantly higher in Group TI0 when compared to Group C $(p=0.00 I)$ and Group T20 $(p=0.004)$. There were no differences between groups in terms of VEGF and Flt-I levels. However, the Flt-I/VEGF ratios were sig-

Table 4. Levels of MDA, Gpx, VEGF, Flt-I, TAC, TOS, and OSI in serum

\begin{tabular}{lcccccccc}
\hline Groups & $\begin{array}{c}\text { MDA } \\
\text { (pmol/g/ } \\
\text { tissue) }\end{array}$ & $\begin{array}{c}\text { Gpx } \\
(\mathbf{n m o l} / \mathbf{m i n} / \mathbf{g} / \\
\text { tissue) }\end{array}$ & $\begin{array}{c}\text { VEGF } \\
\mathbf{( p g / g )}\end{array}$ & $\begin{array}{c}\text { FIt-I } \\
\mathbf{( p g / g )}\end{array}$ & $\begin{array}{c}\text { FIt-I/VEGF } \\
\mathbf{( p g / l )}\end{array}$ & $\begin{array}{c}\text { TAC } \\
\text { (mmol Trolox } \\
\text { Equiv/g) }\end{array}$ & $\begin{array}{c}\text { TOS } \\
\text { (mmol Trolox } \\
\text { Equiv/g) }\end{array}$ & $\begin{array}{c}\text { OSI } \\
\text { (Arbitrary } \\
\text { Units) }\end{array}$ \\
\hline Group S & $1.28 \pm 0.24^{\mathrm{b}, \mathrm{d}}$ & $7.13 \pm 4.44$ & $21.72 \pm 14.25$ & $8.21 \pm 4.90$ & $0.31 \pm 0.40^{\mathrm{c}}$ & $1.34 \pm 0.16^{\mathrm{b}}$ & $18.97 \pm 9.5^{\mathrm{b}, \mathrm{c}}$ & $1.55 \pm 0.77$ \\
Group C & $2.49 \pm 0.46^{\mathrm{a}, \mathrm{c}, \mathrm{d}}$ & $3.29 \pm 1.99^{\mathrm{c}}$ & $19.43 \pm 12.54$ & $7.18 \pm 1.30$ & $0.53 \pm 0.72^{\mathrm{c}}$ & $0.99 \pm 0.10^{\mathrm{a}, \mathrm{c}}$ & $21.56 \pm 8.50^{\mathrm{a}, \mathrm{c}}$ & $1.49 \pm 0.60^{\mathrm{c}}$ \\
Group S10 & $1.56 \pm 0.39^{\mathrm{b}}$ & $8.63 \pm 1.63^{\mathrm{b}, \mathrm{d}}$ & $34.30 \pm 11.22$ & $9.34 \pm 2.21$ & $1.39 \pm 0.60^{\mathrm{a}, \mathrm{b}, \mathrm{d}}$ & $1.21 \pm 0.13^{\mathrm{b}, \mathrm{d}}$ & $13.12 \pm 5.50^{\mathrm{a}, \mathrm{b}}$ & $1.09 \pm 0.45^{\mathrm{b}, \mathrm{d}}$ \\
Group S20 & $2.00 \pm 0.24^{\mathrm{a}, \mathrm{b}}$ & $4.29 \pm 1.78^{\mathrm{c}}$ & $17.46 \pm 8.60$ & $6.70 \pm 1.86^{\mathrm{c}}$ & $0.57 \pm 0.47$ & $1.08 \pm 0.17^{\mathrm{c}}$ & $17.89 \pm 8.03$ & $1.72 \pm 0.55^{\mathrm{c}}$ \\
\hline
\end{tabular}

Results are means \pm SD of two measurements. MDA: Malondialdehyde; Gpx: Glutathione peroxidase; VEGF: Vascular endothelial growth factor; Flt-I: VEGF receptor; TAC: Total antioxidative capacity; TOS: Total oxidant status; OSI: Oxidative stress index.

a: Significantly different when compared to Group S; b: Significantly different when compared to Group C. c: Significantly different when compared to Group SI0; d: Significantly different when compared to Group S20. Comparison of variables between the groups was performed with Kruscal-Wallis test and Mann-Whitney $U$ test.

Table 5. Total scores of pathologic lesions in liver and kidney

\begin{tabular}{|c|c|c|c|c|c|c|}
\hline \multirow[t]{2}{*}{ Rats } & \multicolumn{3}{|c|}{ Histopathological scores in livers } & \multicolumn{3}{|c|}{ Histopathological scores in kidneys } \\
\hline & Group C & Group SIO & Group S20 & Group C & Group SIO & Group S20 \\
\hline 1 & 9 & 8 & 9 & 7 & 4 & 6 \\
\hline 2 & II & 9 & 9 & 9 & 6 & 8 \\
\hline 3 & 9 & 7 & 8 & 7 & 4 & 4 \\
\hline 4 & 10 & 7 & 9 & 10 & 4 & 4 \\
\hline 5 & II & 7 & 8 & 11 & 6 & 4 \\
\hline 6 & 8 & 9 & 7 & 7 & 6 & 4 \\
\hline 7 & 9 & 7 & 9 & 8 & 4 & 6 \\
\hline 8 & $x$ & 7 & 9 & $x$ & 4 & 6 \\
\hline Mean $\pm S D$ & $9.57 \pm 0.42^{\mathrm{a}}$ & $7.62 \pm 0.32^{b}$ & $8.50 \pm 0.26$ & $8.57 \pm 0.57^{a}$ & $4.75 \pm 0.36^{b}$ & $5.25 \pm 0.52^{b}$ \\
\hline
\end{tabular}



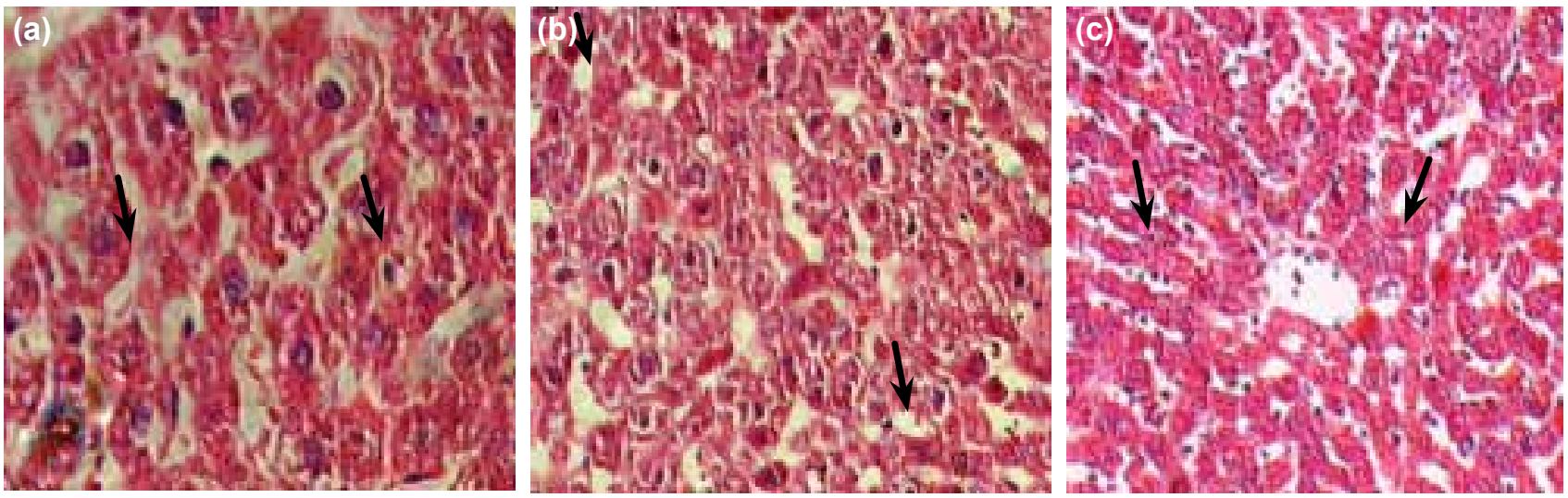

Figure 1. (a-c) Findings of the liver in Group C (H\&E. Bar=15 $\mu \mathrm{m})$. Black Arrow: Degeneration and necrosis of hepatocytes. White Arrows: Mononuclear cell infiltration.

nificantly higher in Group TIO $(p=0.25)$ than in Groups C $(p=0.025)$ and $T 20(p=0.029)$.

Levels of TAC were higher in Group TI0 than in Groups $C(p=0.001)$ and T20 $(p=0.004)$. TOS levels decreased significantly in Group TI0 compared to Groups C $(p=0.00 \mathrm{I})$ and T20 $(p=0.002)$. OSI levels decreased significantly in Group TIO compared to Groups C $(p=0.00 I)$ and T20 $(p=0.00 I)$.

\section{Histopathological Findings}

Histopathological scores in livers and kidneys were shown in (Table 5). Histopathological scores of the liver was found statistically lower in Group TI0 ( $=0.006)$ compared to group C (Fig. I), and this score was also lower in Group T20 when compared to Group C; however, it was not statistically significant. Histopathological scores of the kidneys were significantly lower in Group TIO compared to Groups C ( $p=0.001)$ and T20 ( $p=0.003)$; whereas no difference was detected between Groups T10 and T20 (Fig. 2).
The Correlation of VEGF, Flt-1, and

VEGF/Flt-1 Ratios in Tissue and Serum With Histopathological Findings

The correlation between the liver, kidney and serum values of VEGF, Flt-I, and VEGF/FIt-I ratios and histopathological scores of the organs were shown in Table 6 . There was a negative correlation between pathological scores and Flt-I levels in the liver $(r=-0.522)$. This correlation was statistically significant $(p=0.0 \mathrm{II})$. There were positive correlations between pathological scores and VEGF levels $(r=0.477)$, VEGF/ Flt-I $(r=0.529)$ ratios in kidneys. These correlations were statistically significant $(p=0.009),(p=0.021)$. There was no statically significant correlation between pathological scores in remote organs and serum levels of VEGF, Flt-I, and VEGF/ Flt-I ratios.

\section{DISCUSSION}

Severe burn induces toxic mediators such as ROS and RNS leading to lipid peroxidation, which may have a pivotal role
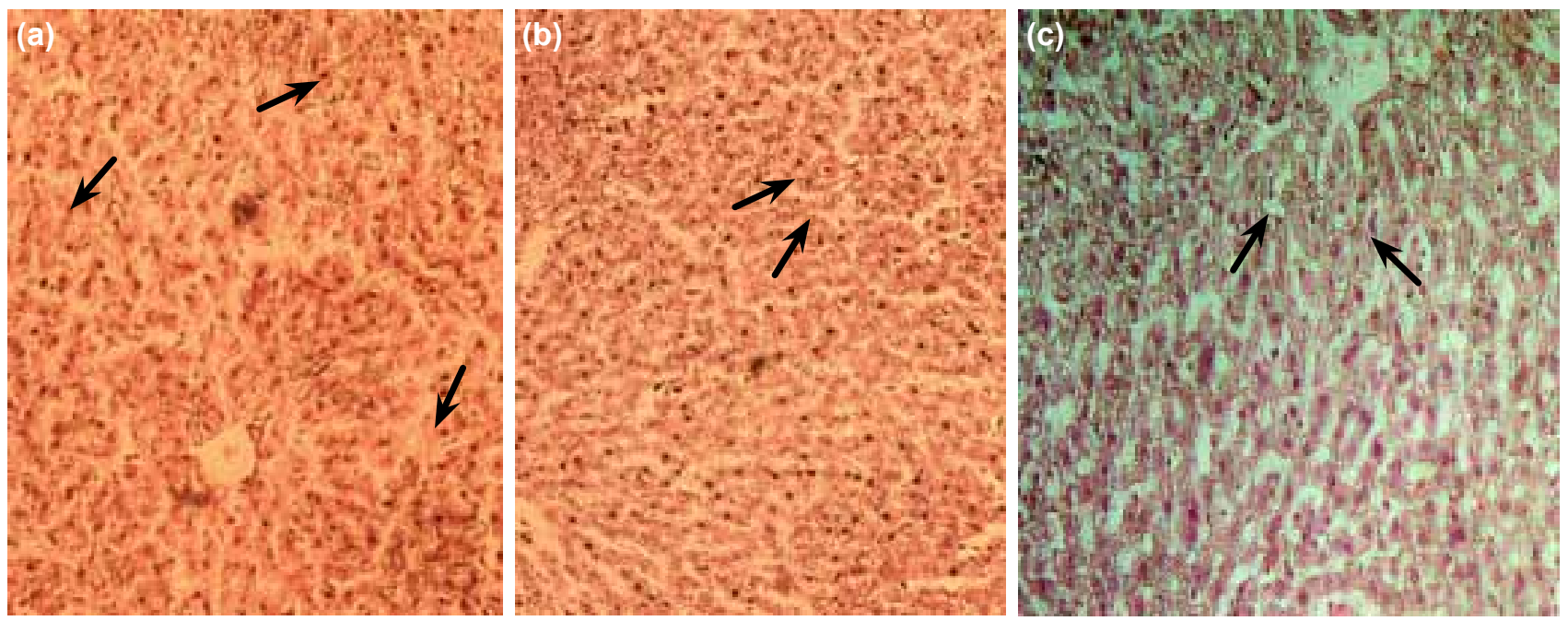

Figure 2. (a-c) Findings of the kidney. Yellow arrows: Hyperemia in glomeruli and mesenchymal cell hyperplasia. (H\&E. Bar=15 $\mu \mathrm{m})$. Yellow arrows in B: Degeneration of tubular epithelium. Black Arrow: Necrosis of tubular epithelium. (H\&E. Bar=30 $\mu \mathrm{m})$. 
Table 6. The correlation of VEGF, FIt-I levels and VEGF/FIt-I ratios in tissues and serum with histopathological findings*

\begin{tabular}{|c|c|c|c|c|c|}
\hline \multicolumn{2}{|c|}{ Parameters } & \multicolumn{2}{|c|}{ Pathological scores in liver ${ }^{*}$} & \multicolumn{2}{|c|}{ Pathological scores in kidney } \\
\hline \multirow[t]{3}{*}{ Liver } & VEGF & $r=0.099$ & $p=0.654$ & & \\
\hline & Flt-I & $r=-0.522^{\#}$ & $\mathrm{p}=0.01 \mathrm{I}^{\S}$ & & \\
\hline & VEGF/FIt-I & $r=0.303$ & $p=0.159$ & & \\
\hline \multirow[t]{3}{*}{ Kidney } & VEGF & & $r=0.477^{\#}$ & $\mathrm{p}=0.02 \mathrm{I}^{\S}$ & \\
\hline & Flt-I & & $r=-0.214$ & $\mathrm{p}=0.328$ & \\
\hline & VEGF/FIt-I & & $r=0.529^{\#}$ & $\mathrm{p}=0.009 \S$ & \\
\hline \multirow[t]{3}{*}{ Serum } & VEGF & $r=-0.046$ & $p=0.833$ & $r=-0.137$ & $p=0.533$ \\
\hline & Flt-I & $r=-0.311$ & $p=0.149$ & $r=-0.289$ & $p=0.181$ \\
\hline & VEGF/FIt-I & $r=-0.164$ & $p=0.454$ & $r=-0.201$ & $p=0.358$ \\
\hline
\end{tabular}

*: A correlation analysis (Speerman test) was used to assess the relationship between histopathological scorings and VEGF/FIt-I ratio; $¥$ : There was a strong positive correlation between serum of histopathological scores of liver and kidneys $(r=0.788$ and $p=0.001)$; \#: Strong correlation; §: $\mathrm{p}<0.05$ (statistically significant); VEGF: Vascular endothelial growth factor; FIt-I: VEGF receptor.

in remote organ injury such as that in the liver and kidneys. [16,40] MDA is an end product of lipid peroxidation and known as a good indicator of cell destruction due to oxidative and nitrosative damage. ${ }^{[1]}$

VEGF is a mediator of angiogenesis and may also have a role in inflammation; ${ }^{[21,41]}$ moreover, NO and VEGF may interact to promote angiogenesis. ${ }^{[42]}$ However, the results showed that a high concentration of NO donors downregulates VEGF expression in endothelial cells. ${ }^{[43]}$ On the other hand, previous studies show endogenous $\mathrm{NO}$ enhances VEGF synthesis. ${ }^{[23,43,44]}$ $\mathrm{NO}$ is known as an inducer of VEGF synthesis under normoxia. However, why NO shows conflicting effects on VEGF is still unclear. An optimal amount of NO may upregulate the VEGF in limited cell lines while an excessive amount of NO inhibits the VEGF expression through an unidentified pathway. [20] All this information reveals that VEGF governs the controlled and regulated phenomenon of angiogenesis, whereas it may also have a role in inflammation dependent remote organ injury. Additionally, Flt-I is known as a VEGF decoy receptor, serving to spatially control VEGF signaling and formation of angiogenic sprouts and in addition to its negative regulatory role in vascular development, Flt-I is important in mounting an inflammatory response and inflammation-associated angiogenesis (denoted 'pathological angiogenesis') through recruitment of bone marrow- derived myelomonocytic cells followed by deposition of angiogenic growth factors. ${ }^{[22]}$

Increase of Gpx enzyme activities following burn related injury protects tissues from the effects of free radicals and lipid peroxidation. ${ }^{[44]}$ TOS and TAC parameters instead of individual oxidant and antioxidant compounds such as MDA, Gpx, and Cat acting in combination with each other may reflect the total effect of oxidant and antioxidant balance in tissues and serum levels. The definition of oxidative stress index (OSI) shows either increased oxidant production or a decreased antioxidant capacity in cells characterized by the release of free radicals, resulting in cellular degeneration which reflects TOS vs TAC ratio. ${ }^{[38,45]}$

In the present study, we specified that sildenafil may have protective effects against severe burn- induced remote organ injury decreasing oxidative and nitrosative stress, as confirmed by biochemical assays and histopathological analysis in both tissues and serum. Our findings fairly presented that treatment with sildenafil increased Gpx and TAC, and decreased MDA, TOS, and OSI. Another important result of our study was that sildenafil had beneficial effects on decreasing the inflammation scores in tissues. Additionally, the $10 \mathrm{mg} / \mathrm{kg}$ sildenafil group had the lowest inflammation scores in both liver and kidneys, in our study. However, no additional benefit was pointed out when the dosage increased to $20 \mathrm{mg} / \mathrm{kg}$. The effects of sildenafil treatment on VEGF and Flt-I in tissue levels appear to be dependent upon dosage and organ. On the other hand, sildenafil treatment appears to be effective on VEGF serum levels through Flt- I. As in previous studies, ${ }^{[17,20,23]}$ sildenafil showed conflicting effects in VEGF values in tissues in our study and these effects may be due to the amount of NO produced by sildenafil. However, not measuring the levels of $\mathrm{NO}$ can be accepted as a limitation of this trial.

Cadirci et al. ${ }^{[32]}$ reported effects of sildenafil (10 and $20 \mathrm{mg} /$ $\mathrm{kg} / \mathrm{p}$.o.) in remote organs, including the lung and kidneys, in a rat model of sepsis. They observed a significant decrease in oxidative stress and inflammation degree by evaluating similar biochemical parameters and histopathological scores, like ours, in the sildenafil-treated groups compared to the control group. However, unlike us, they evaluated the oxidant/antioxidant parameters in only tissue levels, whereas we evaluated them in both tissues and serum. Similarly, Uzun et al. ${ }^{[34]}$ 
demonstrated that sildenafil administration ( $10 \mathrm{mg} / \mathrm{kg} / \mathrm{p} .0$.) in ischemic colonic anastomoses increased GSH levels and promoted healing of anastomosis. Additionally, Iseri et al. ${ }^{[33]}$ found that sildenafil treatment ( $5 \mathrm{mg} / \mathrm{kg} / \mathrm{p} .0$.) decreased MDA and increased GSH levels in tissues and improved the healing of colonic inflammation in rats. Also, in a different trial, Karakoyun et al. ${ }^{[3]]}$ concluded in rat experimentally induced colitis that sildenafil treatment ( $25 \mathrm{mg} / \mathrm{kg} /$ p.o.) decreased MDA and increased GSH levels in colonic tissues and might have a beneficial effect in colitis treatment. Additionally, Zhang et al. ${ }^{[23]}$ used sildenafil treatment $(2 \mathrm{mg} / \mathrm{kg} / \mathrm{p}$.o.) in a rat model of brain ischemia and found out that sildenafil promoted angiogenesis via VEGF. These results supported the findings of the present study and demonstrated positive effects of different dosages of sildenafil treatment on different tissue injuries due to oxidative and nitrosative stress.

In our review of the literature, we were not able to find any previous experimental study using TAC, TOS, and OSI levels to evaluate the oxidative stress in both tissues and serum except our previous study. ${ }^{[9]}$ In our study, while TAC levels in liver tissues were found to be higher, TOS and OSI levels were found to be lower in treatment groups. A similar trend was found in the kidneys, but was not statistically significant. This situation may be accepted as additional evidence for the beneficial effects of sildenafil in tissue levels. Sildenafil seems to have dose dependent positive effects only on TAC levels in terms of serum levels.

Positive effects of sildenafil administration in histopathological evaluations in inflammatory events have been demonstrated in a number of previous studies. ${ }^{[23,30-34,46,47]}$ Histopathological evaluations of those studies also demonstrated the positive effects of various dosages of sildenafil administration (range $2 \pm 25 \mathrm{mg} / \mathrm{kg}$ ) in decreased inflammation scores.

In conclusion, our findings reveal that sildenafil may have a protective effect in scald burn- related remote organ injury by decreasing oxidative and nitrosative stress, as well as inflammation. In addition, the dosage of $10 \mathrm{mg} / \mathrm{kg}$ appears better than $20 \mathrm{mg} / \mathrm{kg}$.

\section{Disclosure}

The authors declare that they have no competing interests as defined by this journal, or other interests that might be perceived to influence the results and discussion reported in this paper.

\section{REFERENCES}

1. Parihar A, Parihar MS, Milner S, Bhat S. Oxidative stress and anti-oxidative mobilization in burn injury. Burns 2008;34:6-17. CrossRef

2. Sittig K, Deitch EA. Effect of bacteremia on mortality after thermal injury. Arch Surg 1988;123:1367-70. CrossRef

3. Ocal K, Avlan D, Cinel I, Unlu A, Ozturk C, Yaylak F, et al. The effect of $\mathrm{N}$-acetylcysteine on oxidative stress in intestine and bacterial translocation after thermal injury. Burns 2004;30:778-84. CrossRef
4. Gürer A, Ozdoğan M, Gökakin AK, Gömceli I, Gülbahar O, Arikök $\mathrm{AT}$, et al. Tissue oxidative stress level and remote organ injury in two-hit trauma model of sequential burn injury and peritoneal sepsis are attenuated with $\mathrm{N}$-acetylcysteine treatment in rats. Ulus Travma Acil Cerrahi Derg 2009;15:1-6.

5. Sasaki J, Fujishima S, Iwamura H, Wakitani K, Aiso S, Aikawa N. Prior burn insult induces lethal acute lung injury in endotoxemic mice: effects of cytokine inhibition. Am J Physiol Lung Cell Mol Physiol 2003;284:L270-8.

6. Steinvall I, Fredrikson M, Bak Z, Sjoberg F. Incidence of early burn-induced effects on liver function as reflected by the plasma disappearance rate of indocyanine green: a prospective descriptive cohort study. Burns 2012;38:214-24. CrossRef

7. Schneider DF, Dobrowolsky A, Shakir IA, Sinacore JM, Mosier MJ, Gamelli RL. Predicting acute kidney injury among burn patients in the 21st century: a classification and regression tree analysis. J Burn Care Res 2012;33:242-51. CrossRef

8. Nguyen LN, Nguyen TG. Characteristics and outcomes of multiple organ dysfunction syndrome among severe-burn patients. Burns 2009;35:93741. CrossRef

9. Gokakin AK, Deveci K, Kurt A, Karakus BC, Duger C, Tuzcu M, et al. The protective effects of sildenafil in acute lung injury in a rat model of severe scald burn: A biochemical and histopathological study. Burns 2013;39:1193-9. CrossRef

10. Magnotti LJ, Xu DZ, Lu Q, Deitch EA. Gut-derived mesenteric lymph: a link between burn and lung injury. Arch Surg 1999;134:1333-41. CrossRef

11. Moore FA. The role of the gastrointestinal tract in postinjury multiple organ failure. Am J Surg 1999;178:449-53. CrossRef

12. Kabasakal L, Sener G, Cetinel S, Contuk G, Gedik N, Yeğen BC. Burninduced oxidative injury of the gut is ameliorated by the leukotriene receptor blocker montelukast. Prostaglandins Leukot Essent Fatty Acids 2005;72:431-40. CrossRef

13. Sabeh F, Baxter CR, Norton SJ. Skin burn injury and oxidative stress in liver and lung tissues of rabbit models. Eur J Clin Chem Clin Biochem 1995;33:323-8.

14. Youn YK, Suh GJ, Jung SE, Oh SK, Demling R. Recombinant human growth hormone decreases lung and liver tissue lipid peroxidation and increases antioxidant activity after thermal injury in rats. J Burn Care Rehabil 1998;19:542-8. CrossRef

15. Horton JW. Free radicals and lipid peroxidation mediated injury in burn trauma: the role of antioxidant therapy. Toxicology 2003;189:75-88. CrossRef

16. Hoşnuter M, Gürel A, Babucçu O, Armutcu F, Kargi E, Işikdemir A. The effect of CAPE on lipid peroxidation and nitric oxide levels in the plasma of rats following thermal injury. Burns 2004;30:121-5. CrossRef

17. Mor F, Quintana FJ, Cohen IR. Angiogenesis-inflammation cross-talk: vascular endothelial growth factor is secreted by activated $T$ cells and induces Th1 polarization. J Immunol 2004;172:4618-23. CrossRef

18. Sato Y, Kanno S, Oda N, Abe M, Ito M, Shitara K, Shibuya M. Properties of two VEGF receptors, Flt-1 and KDR, in signal transduction. Ann N Y Acad Sci 2000;902:201-7. CrossRef

19. Barleon B, Sozzani S, Zhou D, Weich HA, Mantovani A, Marmé D. Migration of human monocytes in response to vascular endothelial growth factor (VEGF) is mediated via the VEGF receptor flt-1. Blood 1996;87:3336-43.

20. Kimura H, Esumi H. Reciprocal regulation between nitric oxide and vascular endothelial growth factor in angiogenesis. Acta Biochim Pol 2003;50:49-59.

21. Altavilla D, Galeano M, Bitto A, Minutoli L, Squadrito G, Seminara P, et al. Lipid peroxidation inhibition by raxofelast improves angiogenesis and wound healing in experimental burn wounds. Shock 2005;24:85-91.

22. Koch S, Tugues S, Li X, Gualandi L, Claesson-Welsh L. Signal transduction by vascular endothelial growth factor receptors. Biochem J 2011;437:169-83. CrossRef 
23. Zhang R, Wang L, Zhang L, Chen J, Zhu Z, Zhang Z, et al. Nitric oxide enhances angiogenesis via the synthesis of vascular endothelial growth factor and cGMP after stroke in the rat. Circ Res 2003;92:308-13. CrossRef

24. Kataru RP, Jung K, Jang C, Yang H, Schwendener RA, Baik JE, et al. Critical role of CD11b+ macrophages and VEGF in inflammatory lymphangiogenesis, antigen clearance, and inflammation resolution. Blood 2009;113:5650-9. CrossRef

25. Gao C, Liu Y, Ma L, Zhang X, Wang S. Effects of Ligustrazine on pulmonary damage in rats following scald injury. Burns 2012;38:743-50. CrossRef

26. Iseri SO, Ersoy Y, Gedik N, Ercan F, Alican I. Protective role of adrenomedullin in burn-induced remote organ damage in the rat. Regul Pept 2008;146:99-105. CrossRef

27. Avlan D, Taşkinlar H, Tamer L, Camdeviren H, Ozturhan H, Oztürk C, et al. Protective effect of trapidil against oxidative organ damage in burn injury. Burns 2005;31:859-65. CrossRef

28. Gürbüz V, Corak A, Yeğen BC, Kurtel H, Alican I. Oxidative organ damage in a rat model of thermal injury: the effect of cyclosporin A. Burns 1997;23:37-42. CrossRef

29. Glossmann H, Petrischor G, Bartsch G. Molecular mechanisms of the effects of sildenafil (VIAGRA). Exp Gerontol 1999;34:305-18. CrossRef

30. Ayten R, Cetinkaya Z, Girgin M, Ozercan I, Ustundag B, Aygen E. The effects of intraperitoneal sildenafil administration on healing of left colonic anastomoses and intra-abdominal adhesion formation in the presence of intra-abdominal infection. Dis Colon Rectum 2008;51:1837-41.

31. Karakoyun B, Uslu U, Ercan F, Aydin MS, Yuksel M, Ogunc AV, et al. The effect of phosphodiesterase -5 inhibition by sildenafil citrate on inflammation and apoptosis in rat experimental colitis. Life Sci 2011;89:402-7.

32. Cadirci E, Halici Z, Odabasoglu F, Albayrak A, Karakus E, Unal D, et al. Sildenafil treatment attenuates lung and kidney injury due to overproduction of oxidant activity in a rat model of sepsis: a biochemical and histopathological study. Clin Exp Immunol 2011;166:374-84. CrossRef

33. Iseri SO, Ersoy Y, Ercan F, Yuksel M, Atukeren P, Gumustas K, et al. The effect of sildenafil, a phosphodiesterase- 5 inhibitor, on acetic acid-induced colonic inflammation in the rat. J Gastroenterol Hepatol 2009;24:1142-8.

34. Uzun H, Konukoglu D, Nuri MK, Ersoy EY, Ozçevik S, Yavuz N. The effects of sildenafil citrate on ischemic colonic anastomotic healing in rats: its relationship between nitric oxide and oxidative stress. World J Surg 2008;32:2107-13. CrossRef
35. Walker DK, Ackland MJ, James GC, Muirhead GJ, Rance DJ, Wastall P, et al. Pharmacokinetics and metabolism of sildenafil in mouse, rat, rabbit, dog and man. Xenobiotica 1999;29:297-310. CrossRef

36. Stevenson JM, Gamelli RL, Shankar R. A mouse model of burn wounding and sepsis. Methods Mol Med 2003;78:95-105.

37. Paglia DE, Valentine WN. Studies on the quantitative and qualitative characterization of erythrocyte glutathione peroxidase. J Lab Clin Med 1967;70:158-69.

38. Erel O. A new automated colorimetric method for measuring total oxidant status. Clin Biochem 2005;38:1103-11. CrossRef

39. Erel O. A novel automated method to measure total antioxidant response against potent free radical reactions. Clin Biochem 2004;37:112-9. CrossRef

40. Demling RH, Lalonde C. Systemic lipid peroxidation and inflammation induced by thermal injury persists into the post-resuscitation period. J Trauma 1990;30:69-74. CrossRef

41. Scaldaferri F1, Vetrano S, Sans M, Arena V, Straface G, Stigliano E, et al. VEGF-A links angiogenesis and inflammation in inflammatory bowel disease pathogenesis. Gastroenterology 2009;136:585-95.e5.

42. Jozkowicz A, Cooke JP, Guevara I, Huk I, Funovics P, Pachinger O, et al. Genetic augmentation of nitric oxide synthase increases the vascular generation of VEGF. Cardiovasc Res 2001;51:773-83. CrossRef

43. Dulak J, Józkowicz A, Ratajska A, Szuba A, Cooke JP, Dembińska-Kieć A. Vascular endothelial growth factor is efficiently synthesized in spite of low transfection efficiency of pSG5VEGF plasmids in vascular smooth muscle cells. Vasc Med 2000;5:33-40. CrossRef

44. Lubos E, Loscalzo J, Handy DE. Glutathione peroxidase-1 in health and disease: from molecular mechanisms to therapeutic opportunities. Antioxid Redox Signal 2011;15:1957-97. CrossRef

45. Erel O. A novel automated direct measurement method for total antioxidant capacity using a new generation, more stable ABTS radical cation. Clin Biochem 2004;37:277-85. CrossRef

46. Hemnes AR, Zaiman A, Champion HC. PDE5A inhibition attenuates bleomycin-induced pulmonary fibrosis and pulmonary hypertension through inhibition of ROS generation and RhoA/Rho kinase activation. Am J Physiol Lung Cell Mol Physiol 2008;294:L24-33. CrossRef

47. Yildirim A, Ersoy Y, Ercan F, Atukeren P, Gumustas K, Uslu U, et al. Phosphodiesterase- 5 inhibition by sildenafil citrate in a rat model of bleomycin-induced lung fibrosis. Pulm Pharmacol Ther 2010;23:215-21.

\title{
DENEYSEL ÇALIŞMA - ÖZET
}

\section{Sildenafilin ağır haşlama yanığı oluşturulan sıçan modelinde karaciğer ve böbrek hasarı üzerine etkisi: Biyokimyasal ve histopatolojik çalışma \\ Dr. Ali Kağan Gökakın, ${ }^{1}$ Dr. Mustafa Atabey, ${ }^{1}$ Dr. Koksal Deveci, ${ }^{2}$ Dr. Enver Sancakdar, ${ }^{2}$ Dr. Mehmet Tuzcu, ${ }^{3}$ Dr. Cevdet Duger, ${ }^{4}$ Dr. Omer Topcu ${ }^{1}$}

\author{
${ }^{1}$ Cumhuriyet Üniversitesi Tıp Fakültesi, Genel Cerrahi Anabilim Dalı, Sivas; \\ ${ }^{2}$ Cumhuriyet Üniversitesi Tıp Fakültesi, Biokimya Anabilim Dalı, Sivas; \\ ${ }^{3}$ Cumhuriyet Üniversitesi Veteriner Fakültesi, Patoloji Anabilim Dalı, Sivas; \\ ${ }^{4}$ Cumhuriyet Üniversitesi Tıp Fakültesi, Anesteziyoloji Anabilim Dalı, Sivas
}

AMAÇ: Ağır yanıklar sistemik enflamasyonu ve reaktif oksijen radikallerinin oluşumunu artırarak lipid peroksidasyonuna öncülük eder ve bu da uzak organ hasarında rol oynayabilir. Sildenafil selektif ve potent bir cyclic guanosine monofosfat ve spesifik bir fosfodiesteraz-5 inhibitörüdür. Sildenafil uzak organlarda enflamasyonu ve oksidatif stresi azaltır. Bu çalışmada, sildenafilin farklı dozlarda uzak organ hasarı üzerine olan etkisi araştırıldı.

GEREÇ VE YÖNTEM: Otuz iki sıçan dört eşit gruba randomize şekilde ayrıldı. Sırasıyla; Sham, kontrol, 10 ve 20 mg/kg sildenafil tedavi grubu olarak adlandırıldı. Doku ve serumda malondialdehit (MDA), vasküler endotelyal büyüme faktörü (VEGF), VEGF reseptör (Flt-I), glutatyon peroksidaz aktivitesi (Gpx), total antioksidan kapasite (TAC) ve total oksidan durum (TOS) seviyeleri ölçüldü. Histopatolojik bulguların değerlendirilmesinde semi kantitatif skorlama sistemi kullanıldı.

BULGULAR: Sildenafilin dokuda Gpx ve Flt değerlerini artıııken, MDA ve VEGF değerlerini azalttığı görüldü. Sildenafilin TAC ve FIt-I serum seviyelerini artırdığı tespit edilse de TOS, OSI ve VEGF seviyelerini azalttığı görüldü.

TARTIŞMA: Sildenafil histopatolojik incelemede uzak organ emflamasyon skorunu azaltır. Sildenafil ağır haşlama yanığına bağlı uzak organ hasarında oksidatif stres ve emflamasyonu azaltarak koruyucu etkiye sahiptir.

Anahtar sözcükler: Haşlama yanı̆̆ı; sildenafil; uzak organ hasarı.

Ulus Travma Acil Cerrahi Derg 20 I4;20(5):319-327 doi: 10.5505/tjtes.20I4.39586 